Original Article

\title{
Exogenous application of bio-stimulant and growth retardant improved the productivity of cotton cultivars under different planting arrangement
}

\author{
A aplicação exógena de bioestimulante e regulador de crescimento na melhoria da \\ produtividade de cultivares de algodão sob diferentes configurações de plantio
}

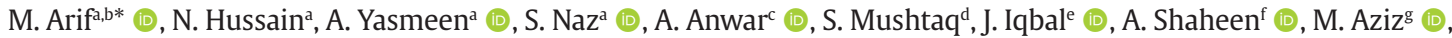 \\ S. A. H. Bukharia and S. H. Shah ${ }^{\text {h }}$ \\ aBahauddin Zakariya University, Multan, Punjab, Pakistan \\ ${ }^{b}$ Directorate of Land Reclamation, Irrigation Department Punjab, Lahore, Pakistan \\ 'Pir Mehr Ali Shah Arid Agriculture University, Rawalpindi, Punjab, Pakistan \\ dUniversity of Wisconsin, Madison, USA \\ 'The Ismia University of Bahawalpur, Punjab, Pakistan \\ ${ }^{\mathrm{f} G o v t . ~ S a d i q ~ C o l l e g e ~ W o m e n ~ U n i v e r s i t y ~ B a h a w a l p u r, ~ P u n j a b, ~ P a k i s t a n ~}$ \\ gBarani Agricultural Research Institute, Chakwal, Punjab, Pakistan \\ ${ }^{\text {h} A l l a m a ~ I q b a l ~ O p e n ~ U n i v e r s i t y, ~ I s l a m a b a d, ~ P a k i s t a n ~}$
}

\begin{abstract}
Optimum planting arrangement is an important attribute for efficient utilization of available resources and to obtain high yield of cotton. Application of plant growth promoter and retardant on cotton in improved planting density are the innovative techniques in the establishment of more productive cotton crop. Therefore, we planned a field study to assess the role of bio-stimulant and growth retardant in the resource utilization efficiency of cotton cultivars planted under variable row spacing at Agronomic Research Area Bahauddin Zakariya University and Usmania Agricultural Farm Shujabad during Kharif 2012. Experimental treatments consisted of cotton genotypes viz. CIM-573 and CIM-598, cultivated under conventional $(75 \mathrm{~cm})$, medium $(50 \mathrm{~cm})$ and ultra-narrow row spacing $(25 \mathrm{~cm}$ ) with foliar spray of bio-stimulant (moringa leaf extract) and growth retardant (mepiquate chloride), either sole or in combination, keeping distilled water as a control. Exogenously applied MLE alone and MLE + MC significantly enhanced the number of squares, flowers and green bolls per plant leading to higher cotton seed and lint yield of CIM 598 cultivar cultivated under conventional row spacing. While application of MC alone and MLE + MC produced maximum micronaire value, fiber strength and fiber uniformity ratio of CIM 573 cultivar cultivated under conventional row spacing. The results suggested that application of MLE is a possible approach to enhance the cotton productivity and the use of MC to enhance the fiber quality attributes under conventional row spacing.
\end{abstract}

Keywords: planting arrangement, row spacing, cotton seed yield, fiber quality, moringa leaf extract.

\begin{abstract}
Resumo
A configuração ideal de plantio é um atributo importante para a utilização eficiente dos recursos disponíveis e para obter alto rendimento de algodão. A aplicação de promotores de crescimento de plantas e reguladores de crescimento no algodão em uma densidade de plantio adequada são técnicas inovadoras na obtenção de safras de algodão mais produtivas. Portanto, foi planejado um estudo de campo para avaliar o papel de um bioestimulante e um regulador de crescimento na eficiência da utilização de recursos de cultivares de algodão plantadas com espaçamento variável entre linhas na Área de Pesquisa Agronômica Universidade Bahauddin Zakariya e Usmania Agricultural Farm Shujabad durante Kharif 2012. Os tratamentos experimentais consistiram em genótipos de algodão viz. CIM-573 e CIM-598, cultivadas sob espaçamento convencional (75 cm), médio (50 $\mathrm{cm}$ ) e ultraestreito $(25 \mathrm{~cm})$ e pulverização foliar de bioestimulante (extrato de folha de moringa) e regulador de crescimento (cloreto de mepiquato)), sozinho ou combinado, mantendo a água destilada como controle. O MLE aplicado exogenamente sozinho e o MLE + MC aumentaram significativamente o número de quadrados, flores e cápsulas verdes por planta, levando a um maior rendimento de sementes e fibra de algodão da cultivar CIM 598 cultivada sob espaçamento convencional entre fileiras. Enquanto a aplicação de MC sozinho e MLE + MC produziu valor máximo de micronaire, resistência da fibra e razão de uniformidade da fibra da cultivar CIM 573 cultivada
\end{abstract}

*e-mail: jamarif@gmail.com

Received: May 24, 2020 - Accepted: December 11, 2020 
sob espaçamento convencional entre linhas. Os resultados sugeriram que a aplicação do MLE é uma abordagem possível para aumentar a produtividade do algodão e o uso de MC para aprimorar os atributos de qualidade da fibra no espaçamento convencional entre linhas.

Palavras-chave: configuração de plantio, espaçamento entre linhas, produção de sementes de algodão, qualidade da fibra, extrato de folha de moringa.

\section{Introduction}

Establishment of an appropriate plant stand is a basic agronomic factor to improve the crop productivity (Venugopalan et al., 2013). Planting arrangement directly impacts the light interception, nutrients and moisture accessibility (Echer and Rosolem, 2015) which affects the plant height, branching arrangement, fruiting position and productivity. The ultra-narrow row spaced cotton has long been seen as a probable substitute system to conventional systems (Nawaz et al., 2015). Reduction in row spacing can ensue improved solar radiation incidence earlier in the season due to early canopy development and closure that assist in weed suppression (Wright et al., 2011). However, self-shading can hamper light interception on lower leaves as the canopy closes, reducing the photosynthesis and plant net assimilates production (Lv et al., 2013). Cotton as the rubisco has a great empathy with carbon dioxide and oxygen and photorespiration enhanced in lower radiation interception (Echer and Rosolem, 2015). Consequently, ethylene and sugar ratio enhances and the abscission percentage of reproductive structures is greater, ensuing in loss of cotton productivity and fiber quality attributes (Yasmeen et al., 2016).

Cotton being indeterminate in nature, its vegetative and reproductive growth occurs simultaneously (Oosterhuis, 2001). Excessive vegetative growth results in more shade, higher abscission of flowers and imbalance between source and sink is the reason of the unpredictable behavior. Under such conditions, foliar application of mepiquate chloride (MC) is considered beneficial for regulating the plant structure and leads to a compact plant structure (Rosolem et al., 2013) ensuing from reduced internode elongation, decreased main stem nodes and leaf area in cotton (Yasmeen et al., 2016). It also tends to improve the solar radiation interception to the lower leaves and chlorophyll concentration, enhancing the activity of leaves subtending promptly filling bolls in the lower canopy. However, mepiquat chloride that adjusts the position of bolls on the plant, it does not usually modify the overall boll retaining proportion (Wilson Júnior et al., 2007).

Another possible way to improve the growth and productivity is the application of some bio-stimulants (Balakumbahan and Rajamani, 2010). Among several biostimulants, Moringa oleifera extract (MLE) had fascinated the great attention of researchers. MLE, being rich in ascorbates, amino acids, potassium, calcium, iron and zeatin like growth promoting substances, enhance the growth and productivity (Yasmeen et al., 2018; Arif et al., 2019a). Hence, its application improves the growth of young plants, extends the lifespan, produces more and superior fruits, accelerates resistance to diseases and pests and usually boosts up yield up to $20-35 \%$ (Yasmeen et al., 2013). In the work presented here, we aimed to evaluate the role of natural growth enhancer and synthetic growth retardant on the yield components and fiber quality of cotton cultivars cultivated under different row spacing.

\section{Materials and Methods}

Field study was planned to discover the role of natural growth promoter and synthetic growth retardant on the productivity of cotton genotypes under different row spacing at Multan and Shujaabad during 2012. The soil texture was silt loam, with pH 9.3 and 7.90, EC 0.99 and $1.11 \mathrm{dS} \mathrm{m}^{-1}$, total nitrogen 0.021 and $0.0521 \%$, available phosphorus 3.00 and 7.05 ppm, exchangeable potassium 180 and 148 ppm and organic matter 0.34 and $0.66 \%$ in Shujabad and Multan, respectively.

The trial was designed in completely randomized with factorial structure with 3 repeats. The study was encompassed of two cotton genotypes i.e., CIM-573 (non $\mathrm{Bt}$ ) and CIM-598 (Bt), grown under conventional $(75 \mathrm{~cm})$, medium $(50 \mathrm{~cm})$ and improved ultra-narrow row spacing $(25 \mathrm{~cm})$ with foliar spray of bio-stimulant, moringa leaf extract (MLE) and growth retardant, mepiquate chloride (MC) either sole or in combinations, keeping distilled water as a control. Foliar spray was applied at the beginning, 45 and 90 days of bloom.

\subsection{Preparation of moringa leaf extract}

Fresh leaves and tender twigs of Moringa oleifera plants grown in botanical garden of Bahauddin Zakariya University, Multan was harvested and washed several times with distilled water. This material was frozen $\left(-5^{\circ} \mathrm{C}\right)$ for 12 hours and pressed for extraction in a locally fabricated machine according to procedure described by Arif et al. (2019b). This extract was filtered twice by using Whatman No. 1 filter paper and then centrifuged at $8000 \mathrm{~g}$ for $15 \mathrm{~min}$ and diluted 30 times by using distilled water.

\subsection{Crop husbandry}

Experimental area was irrigated 12 days before sowing. Proper seedbed was prepared with rotavator and cultivator and then beds were properly formed. Seeds of cotton genotypes were dibbled manually on $28^{\text {th }}$ March 2012. First irrigation was applied after dibbling to achieve higher germination percentage. Following irrigations were applied depending upon the soil moisture conditions until second week of September. To maintain optimal plant population, gap filling and thinning was done on $12^{\text {th }}$ and $23^{\text {rd }}$ day of emergence, respectively. Suggested doses of nitrogen fertilizer (145 kg ha-1 for Bt and $114 \mathrm{~kg} \mathrm{ha}^{-1}$ for non Bt genotypes), was used in three equal splits viz. at sowing time, beginning of blossoming and peak flowering stage. Whereas endorsed doses of phosphorus and potassium fertilizers i.e. 56 and $62 \mathrm{~kg} \mathrm{ha}^{-1}$ were broadcasted at the time of sowing. Weeds were controlled with the application of 
pre-emergence herbicide of Pendimethalin (Stomp-330E at $2.5 \mathrm{~L} \mathrm{ha}^{-1}$ ), with two-hand weeding at the $20^{\text {th }}$ and $30^{\text {th }}$ days after sowing. Insect and pest control was achieved with spray assessments based on threshold scouting. All other agronomic practices were followed using recommended state package practices for raising the crop.

\subsection{Statistical analysis}

Collected data were statistical analyzed by M STAT software and difference was compared by using DMR test at 5\% probability (Steel et al., 1997).

\section{Results}

Optimum planting arrangement defines interplant competition for essential nutrients, solar radiation interception and moisture thus; resource use efficiency of genotypes may increase or decreased. Maximum yield potential of a genotype can be achieved by attaining optimal plant density. In present study, leaf application of bio-stimulant and growth retardant considerably influenced all the yield and fiber quality attributes of cotton cultivars cultivated under different planting arrangement. Exogenously applied MLE + MC produced significantly higher number of squares (flower bud that first appear on the plant as reproductive growth begins called squares) (Figure 1) and flowers per plant from CIM 598 cultivated under conventional row spacing (Figure 2). However, minimum number of squares and flowers was observed in CIM 573 cultivated in compact row spacing of $25 \mathrm{~cm}$ from control plots at both sites (Figure 1 and 2).
Exogenously applied MLE + MC considerably increased the bolls per plant at 90 and 120 DAS from CIM 598 cultivated under conventional row spacing. While exogenous application of MLE produced maximum bolls at 150 and 180 DAS from CIM 598 cultivated under conventional row spacing. Minimum bolls were observed from CIM 573 at all growth stages cultivated under compact row spacing of $25 \mathrm{~cm}$ from control plots at both sites (Figure 3).

Exogenously applied MLE produced maximum cotton seed yield from CIM 598 cultivated under optimum row spacing of $75 \mathrm{~cm}$ at both sites (Table 1). Whereas minimum cotton seed yield was observed from CIM 573 cultivated under medium row spacing of $50 \mathrm{~cm}$ documented from control plots. Leaf application of MLE + MC produced maximum lint yield from Bt cotton cultivar CIM 598 cultivated under optimum row spacing of $75 \mathrm{~cm}$ in Multan. Whereas exogenously applied MLE produced significantly higher lint yield from CIM 598 cultivated under optimum row spacing of $75 \mathrm{~cm}$ against the lowest was observed from control plots in CIM 573 cultivated under spacing of $50 \mathrm{~cm}$ (Table 1 ).

Exogenously applied MLE and MC on cotton genotypes cultivated under different row spacing had no significant influence on micronaire value in Multan. However, leaf application of growth regulators on non Bt cultivar CIM 573 produced higher micronaire value and fiber strength as compared to Bt cultivar CIM 598 in Shujabad and in both sites, respectively. Exogenously applied MLE + MC on cotton genotypes cultivated under different row spacing had no significant effect on fiber maturity ratio in both sites. Leaf application of MLE + MC and sole application

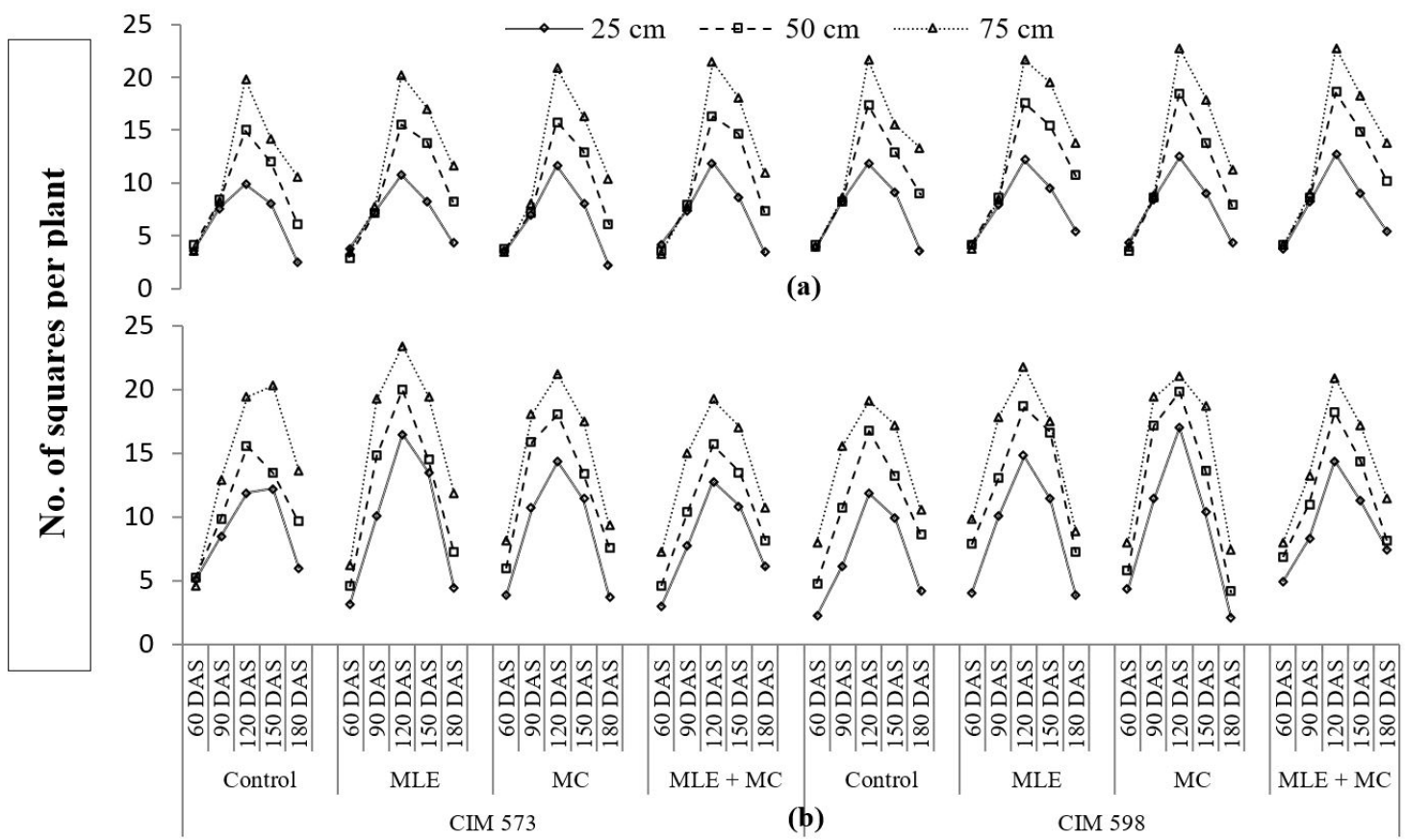

Figure 1. Influence of MLE and MC on squares per plant of cotton genotypes cultivated under different planting arrangement in Multan (a) and Shujabad (b). 


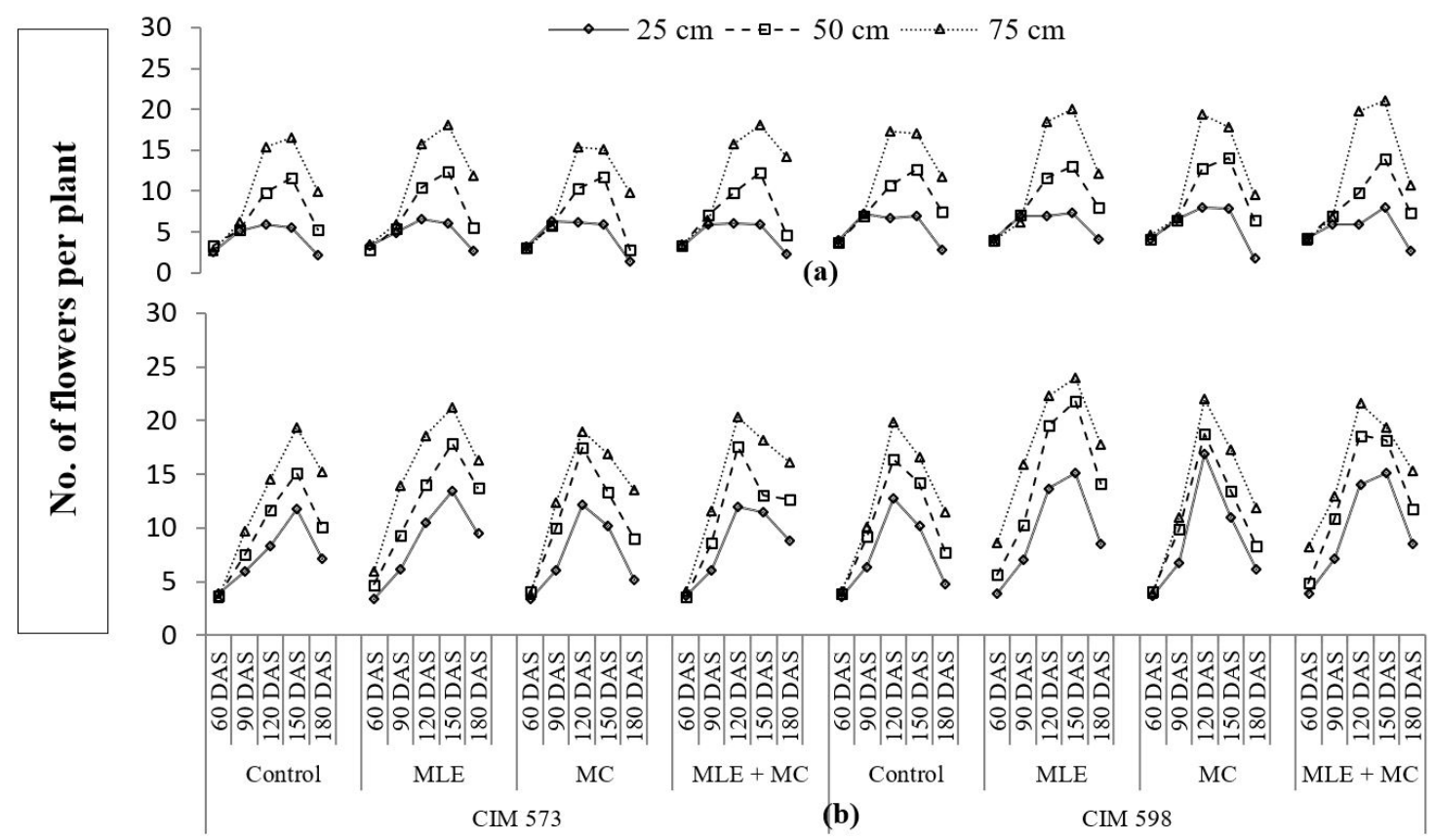

Figure 2. Influence of MLE and MC on flowers per plant of cotton genotypes cultivated under different planting arrangement in Multan (a) and Shujabad (b).

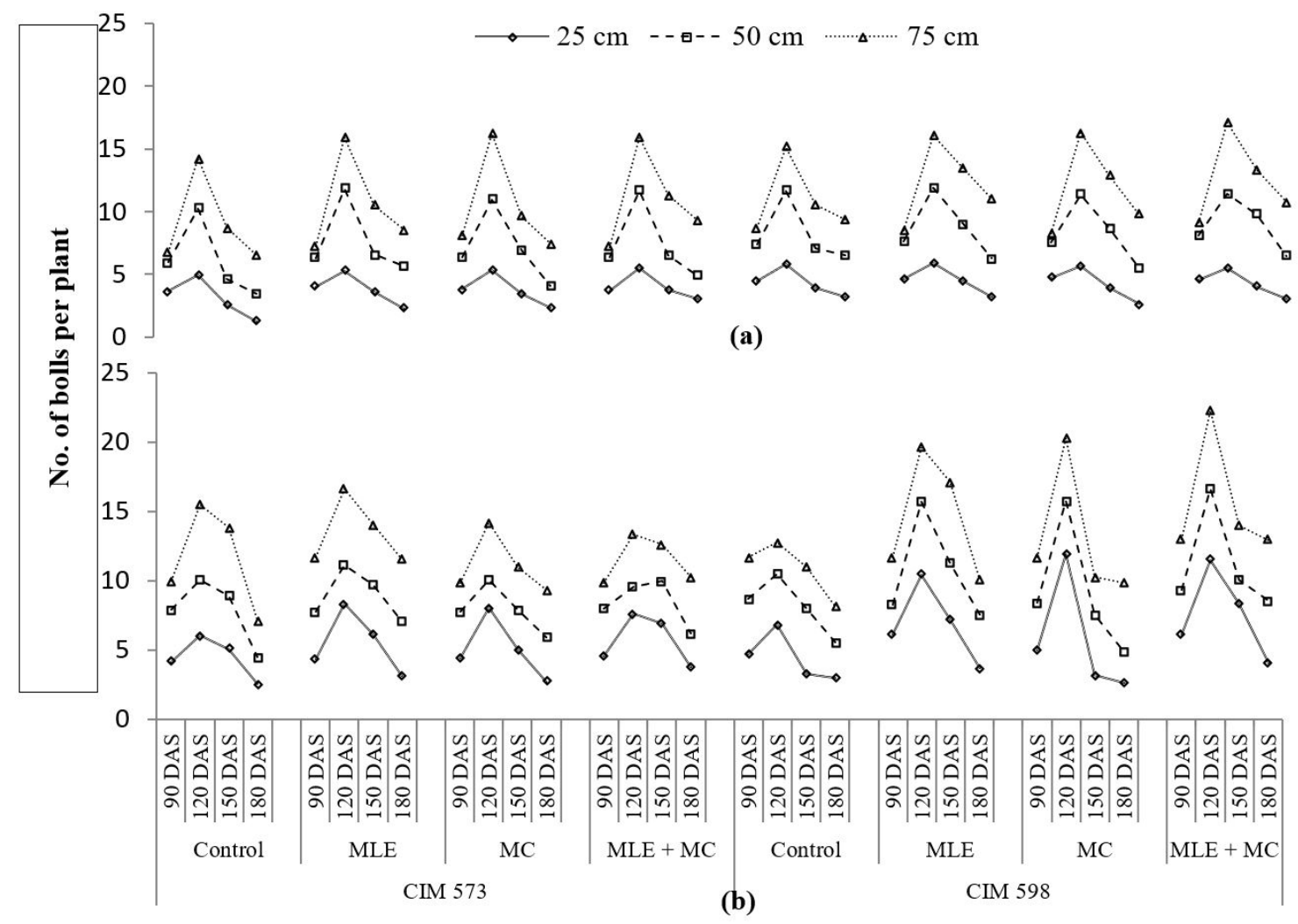

Figure 3. Influence of MLE and MC on bolls per plant of cotton genotypes cultivated under different planting arrangement in Multan (a) and Shujabad (b). 
Table 1. Influence of MLE and MC on yield and fiber contributing attributes of cotton cultivars cultivated under different planting arrangement.

\begin{tabular}{|c|c|c|c|c|c|c|c|c|}
\hline \multicolumn{3}{|c|}{ Treatments } & \multicolumn{2}{|c|}{$\begin{array}{l}\text { Cotton seed yield } \\
\qquad\left(\mathrm{kg} \mathrm{ha}^{-1}\right)\end{array}$} & \multicolumn{2}{|c|}{$\begin{array}{l}\text { Lint yield } \\
\left(\mathrm{kg} \mathrm{ha}^{-1}\right)\end{array}$} & \multicolumn{2}{|c|}{$\begin{array}{l}\text { Micronaire } \\
\left(\mu \text { inch }^{-1}\right)\end{array}$} \\
\hline Cultivar & $\begin{array}{l}\text { Foliar } \\
\text { spray }\end{array}$ & $\begin{array}{c}\text { Row } \\
\text { spacing(cm) }\end{array}$ & Multan & Shujabad & Multan & Shujabad & Multan & Shujabad \\
\hline \multirow[t]{12}{*}{ CIM 573} & \multirow{3}{*}{$\begin{array}{l}\text { Distilled } \\
\text { water }\end{array}$} & 25 & $809.6 \mathrm{fg}$ & $998.1 \mathrm{gh}$ & $508.8 \mathrm{fg}$ & 574.9 hi & 3.643 & $3.697 \mathrm{a}$ \\
\hline & & 50 & $739.4 \mathrm{~g}$ & $914.8 \mathrm{~h}$ & $499.8 \mathrm{~g}$ & $510.7 \mathrm{i}$ & 3.630 & $3.677 \mathrm{a}$ \\
\hline & & 75 & $989.6 \mathrm{eg}$ & 1050. fh & $674.4 \mathrm{dg}$ & $694.9 \mathrm{fh}$ & 3.627 & $3.713 \mathrm{a}$ \\
\hline & \multirow[t]{3}{*}{ MLE } & 25 & $982.5 \mathrm{eg}$ & 1234. cg & $641.2 \mathrm{eg}$ & $747.1 \mathrm{dh}$ & 3.693 & $3.660 \mathrm{a}$ \\
\hline & & 50 & 1039. cg & 1189. ch & $689.4 \mathrm{dg}$ & $799.9 \mathrm{cg}$ & 3.680 & $3.673 \mathrm{a}$ \\
\hline & & 75 & 1177. bf & 1280. cg & 791.5ce & $873.4 \mathrm{cf}$ & 3.677 & $3.693 \mathrm{a}$ \\
\hline & \multirow[t]{3}{*}{ MC } & 25 & 1053. cg & 1287. cg & $692.8 \mathrm{dg}$ & $739.5 \mathrm{dh}$ & 3.670 & $3.670 \mathrm{a}$ \\
\hline & & 50 & $985.5 \mathrm{eg}$ & 1089. eh & $671.0 \mathrm{dg}$ & $662.3 \mathrm{gi}$ & 3.663 & $3.693 \mathrm{a}$ \\
\hline & & 75 & 1143. cf & 1082. eh & 782.3 ce & 708.0 eh & 3.653 & $3.703 \mathrm{a}$ \\
\hline & \multirow{3}{*}{$\begin{array}{l}\text { MLE + } \\
\text { MC }\end{array}$} & 25 & 1131. cf & 1238. cg & 736.0 de & $751.6 \mathrm{ch}$ & 3.677 & $3.673 \mathrm{a}$ \\
\hline & & 50 & 1087.cg & 1168. ch & $728.3 \mathrm{df}$ & $767.9 \mathrm{cg}$ & 3.677 & $3.707 \mathrm{a}$ \\
\hline & & 75 & 1222.ae & 1250. cg & 808.0 ce & $873.1 \mathrm{cf}$ & 3.680 & $3.663 \mathrm{a}$ \\
\hline \multirow[t]{12}{*}{ CIM 598} & \multirow{3}{*}{$\begin{array}{l}\text { Distilled } \\
\text { water }\end{array}$} & 25 & 1110. cg & 1181. ch & 699.3dg & $760.6 \mathrm{ch}$ & 3.553 & $3.553 \mathrm{~b}$ \\
\hline & & 50 & 997.2dg & 1101. dh & $644.2 \mathrm{eg}$ & $740.3 \mathrm{dh}$ & 3.553 & $3.567 \mathrm{~b}$ \\
\hline & & 75 & 1383. ad & 1385. be & 891.0bd & $946.3 \mathrm{bc}$ & 3.560 & $3.530 \mathrm{~b}$ \\
\hline & \multirow[t]{3}{*}{ MLE } & 25 & 1189. bf & 1324. cf & 782.5 ce & $823.0 \mathrm{cg}$ & 3.560 & $3.497 \mathrm{~b}$ \\
\hline & & 50 & 1121. cg & 1198. ch & 742.5 de & $802.2 \mathrm{cg}$ & 3.550 & $3.537 \mathrm{~b}$ \\
\hline & & 75 & 1569. a & 1697. a & 1032. ab & 1188. a & 3.547 & $3.560 \mathrm{~b}$ \\
\hline & \multirow[t]{3}{*}{ MC } & 25 & 1291. ae & 1395. bd & 864.0be & 901.6 ce & 3.533 & $3.517 \mathrm{~b}$ \\
\hline & & 50 & 1180. bf & 1194. ch & 819.3be & $819.2 \mathrm{cg}$ & 3.537 & $3.483 \mathrm{~b}$ \\
\hline & & 75 & 1418.ac & 1352. cf & $993.2 \mathrm{ac}$ & 903.3 се & 3.543 & $3.487 \mathrm{~b}$ \\
\hline & \multirow[t]{3}{*}{$\mathrm{MLE}+\mathrm{MC}$} & 25 & 1342. ae & 1434. ac & 898.7ad & $925.0 \mathrm{~cd}$ & 3.557 & $3.510 \mathrm{~b}$ \\
\hline & & 50 & 1139. cf & 1293. cg & 797.5ce & $855.5 \mathrm{cg}$ & 3.547 & $3.513 \mathrm{~b}$ \\
\hline & & 75 & 1549.ab & 1650. ab & 1103. a & 1104. ab & 3.540 & $3.533 \mathrm{~b}$ \\
\hline LSD $0.05 p=$ & & & 325.33 & 252.41 & 190.55 & 162.93 & n.s & 0.09 \\
\hline
\end{tabular}

of MC on non Bt cultivar CIM 573 grown under $75 \mathrm{~cm}$ row spacing produced significantly higher fiber uniformity ratio in Multan and Shujabad, respectively. Minimum fiber uniformity ratio was observed from Bt cultivar CIM 598 cultivated under compact spacing of $25 \mathrm{~cm}$ in control plots (Table 2).

\section{Discussion}

Foliar spray of natural growth enhancer and synthetic growth retardant modified the physiological processes of cotton genotypes cultivated under various row spacing. Cotton seed and lint yield indicated the cumulative influence of different yield contributing parameters. Exogenously applied MLE + MC produced significantly higher cotton seed yield and its contributing parameters from CIM 598 cultivated under row spacing of $75 \mathrm{~cm}$.
MLE is enriched source of essential nutrients and growth promoting hormones that improved the procedure of photosynthesis which improved the yield components. Such enhancements in productivity are associated with higher number of bolls, regulation in source-sink association and postponed the senescence (Yasmeen et al., 2016). Its application also enhanced the biomass production and its translocation into various plant parts depends upon the photosynthetic capability of a plant (Manjunatha et al., 2010). Similarly, foliar spray of MC is used to regulate the vegetative and reproductive growth and sustaining internal hormonal balance, effective sink source relationship, which improved yield contributing parameters depending on the enhanced photosynthetic activity (Sawan et al., 2006; Gwathmey and Clement, 2010). Its application considerably improved the yield might be due to the fact that it controls the new growth with controlling the vegetative growth and accordingly 
Table 2. Influence of MLE and MC on fiber contributing attributes of cotton cultivars cultivated under different planting arrangement.

\begin{tabular}{|c|c|c|c|c|c|c|c|c|}
\hline \multicolumn{3}{|c|}{ Treatments } & \multicolumn{2}{|c|}{ Fiber strength $\left(\mathrm{g} \mathrm{tex}^{-1}\right)$} & \multicolumn{2}{|c|}{ Fiber maturity ratio } & \multicolumn{2}{|c|}{ Fiber uniformity ratio } \\
\hline Cultivar & $\begin{array}{l}\text { Foliar } \\
\text { spray }\end{array}$ & $\begin{array}{c}\text { Row } \\
\text { spacing }(\mathrm{cm})\end{array}$ & Multan & Shujabad & Multan & Shujabad & Multan & Shujabad \\
\hline \multirow[t]{12}{*}{ CIM 573} & \multirow{3}{*}{$\begin{array}{l}\text { Distilled } \\
\text { water }\end{array}$} & 25 & $34.97 \mathrm{a}$ & $34.63 \mathrm{a}$ & 0.8667 & 0.8633 & 84.19ad & $84.36 \mathrm{~b}$ \\
\hline & & 50 & $35.32 \mathrm{a}$ & $34.74 \mathrm{a}$ & 0.8733 & 0.8467 & 84.32ad & $84.27 \mathrm{~b}$ \\
\hline & & 75 & $35.33 \mathrm{a}$ & $35.03 \mathrm{a}$ & 0.8700 & 0.8533 & $84.40 \mathrm{ac}$ & $84.42 \mathrm{ab}$ \\
\hline & \multirow[t]{3}{*}{ MLE } & 25 & $35.29 a$ & $34.51 \mathrm{a}$ & 0.8767 & 0.8567 & 84.35ad & $84.55 \mathrm{ab}$ \\
\hline & & 50 & $35.37 \mathrm{a}$ & $34.44 \mathrm{a}$ & 0.8733 & 0.8400 & 84.67ab & $84.60 \mathrm{ab}$ \\
\hline & & 75 & $35.35 \mathrm{a}$ & $34.64 \mathrm{a}$ & 0.8767 & 0.8700 & $85.02 \mathrm{a}$ & $84.51 \mathrm{ab}$ \\
\hline & \multirow[t]{3}{*}{ MC } & 25 & $35.34 \mathrm{a}$ & $34.49 \mathrm{a}$ & 0.8733 & 0.8500 & 84.29ad & $84.31 \mathrm{~b}$ \\
\hline & & 50 & $35.44 \mathrm{a}$ & $34.80 \mathrm{a}$ & 0.8733 & 0.8533 & 84.38ad & $84.30 \mathrm{~b}$ \\
\hline & & 75 & $35.46 \mathrm{a}$ & $34.77 \mathrm{a}$ & 0.8767 & 0.8633 & $84.39 \mathrm{ac}$ & $85.12 \mathrm{a}$ \\
\hline & \multirow[t]{3}{*}{$\mathrm{MLE}+\mathrm{MC}$} & 25 & $35.31 \mathrm{a}$ & $34.68 \mathrm{a}$ & 0.8700 & 0.8600 & 84.68ab & $84.50 \mathrm{ab}$ \\
\hline & & 50 & $35.35 \mathrm{a}$ & $34.42 \mathrm{a}$ & 0.8800 & 0.8667 & $84.80 \mathrm{a}$ & $84.90 \mathrm{ab}$ \\
\hline & & 75 & $35.46 \mathrm{a}$ & $34.54 \mathrm{a}$ & 0.8767 & 0.8733 & $85.06 \mathrm{a}$ & $84.42 \mathrm{ab}$ \\
\hline \multirow[t]{12}{*}{ CIM 598} & \multirow{3}{*}{$\begin{array}{c}\text { Distilled } \\
\text { water }\end{array}$} & 25 & $29.85 \mathrm{~b}$ & $29.29 \mathrm{~cd}$ & 0.8167 & 0.8067 & $82.66 \mathrm{~g}$ & $82.35 \mathrm{~d}$ \\
\hline & & 50 & $30.11 \mathrm{~b}$ & $29.17 \mathrm{~d}$ & 0.8100 & 0.8100 & $82.77 \mathrm{fg}$ & $82.59 \mathrm{~cd}$ \\
\hline & & 75 & $30.15 \mathrm{~b}$ & 29.61 bd & 0.8167 & 0.8167 & $83.08 \mathrm{eg}$ & $82.37 \mathrm{~d}$ \\
\hline & \multirow[t]{3}{*}{ MLE } & 25 & $29.94 \mathrm{~b}$ & $29.16 \mathrm{~d}$ & 0.8167 & 0.8000 & $83.47 \mathrm{cg}$ & $82.64 \mathrm{~cd}$ \\
\hline & & 50 & $30.17 \mathrm{~b}$ & $29.91 \mathrm{bd}$ & 0.8233 & 0.8200 & $83.52 \mathrm{cg}$ & $82.67 \mathrm{~cd}$ \\
\hline & & 75 & $30.33 \mathrm{~b}$ & 29.74 bd & 0.8100 & 0.8267 & 83.82be & $83.04 \mathrm{~cd}$ \\
\hline & \multirow[t]{3}{*}{ MC } & 25 & $30.00 \mathrm{~b}$ & $29.43 \mathrm{~cd}$ & 0.8167 & 0.8200 & $83.18 \mathrm{eg}$ & $82.68 \mathrm{~cd}$ \\
\hline & & 50 & $30.08 \mathrm{~b}$ & $29.70 \mathrm{bd}$ & 0.8167 & 0.8167 & $83.21 \mathrm{eg}$ & $82.86 \mathrm{~cd}$ \\
\hline & & 75 & $30.17 \mathrm{~b}$ & $30.35 \mathrm{~b}$ & 0.8267 & 0.8233 & $83.59 \mathrm{cf}$ & $83.13 \mathrm{c}$ \\
\hline & \multirow[t]{3}{*}{$\mathrm{MLE}+\mathrm{MC}$} & 25 & $30.13 \mathrm{~b}$ & $29.80 \mathrm{bd}$ & 0.8233 & 0.8100 & 83.43dg & $82.79 \mathrm{~cd}$ \\
\hline & & 50 & $30.19 \mathrm{~b}$ & $29.42 \mathrm{~cd}$ & 0.8267 & 0.8167 & 83.73be & $82.97 \mathrm{~cd}$ \\
\hline & & 75 & $30.21 b$ & 30.04 bc & 0.8267 & 0.8267 & 83.81be & $82.87 \mathrm{~cd}$ \\
\hline LSD $0.05 p=$ & & & 1.69 & 2.15 & n.s & n.s & 0.890 & 0.63 \\
\hline
\end{tabular}

improve reproductive growth by permitting the plants to translocate photosynthates towards the reproductive organs (Yasmeen et al., 2016). Consequently, MC treated plants have bolls with more photo-assimilate provided sink for carbohydrates and further metabolites (Kumar et al., 2004). Higher cotton seed and lint yield with wider row spacing of $75 \mathrm{~cm}$ was the direct effect of higher number of bolls, that can be credited to higher availability of nutrients, solar radiation and moisture that improved the photosynthetic efficiency which enhanced the accretion of metabolites with direct effect on bolls (Iqbal et al., 2012). Higher fiber quality attributes were perceived with the foliar spray of MLE and MC from non Bt cotton cultivars cultivated under row spacing of $75 \mathrm{~cm}$. Several factors affecting the fiber quality attributes, of which role of genotype is the most importance than agronomic practices (Bednarz et al., 2005). Genotype offers a significant role in fiber development (Jordan, 2001). The extent of cellulose deposited controls the fineness, fiber maturity and strength (Ramey, 1999).

\section{References}

ARIF, M., HUSSAIN, N. and YASMEEN, A., 2019a. Influence of bio-stimulant and potassium sources on the productivity of cotton. The Journal of Animal and Plant Sciences, vol. 29, no. 6, pp. 1643-1653.

ARIF, M., KAREEM, S.H.S., AHMAD, N.S., HUSSAIN, N., YASMEEN, A., ANWAR, A., NAZ, S., IQBAL, J., SHAH, G.A. and ANSAR, M., 2019b. Exogenously applied bio-stimulant and synthetic fertilizers to improve the growth, yield and fiber quality of cotton. Sustainability, vol. 11, no. 7, pp. 1-14. http://dx.doi. org/10.3390/su11072171.

BALAKUMBAHAN, R. and RAJAMANI, K., 2010. Effect of biostimulant on growth and yield of senna (Cassia angustifuliavar KKM.1). Journal of Horticultural Science \& Ornamental Plants, vol. 2, pp. 16-18.

BEDNARZ, C.W., SHURLEY, W.D., ANTHONY, W.S. and NICHOLS, R.L., 2005. Yield, quality, and profitability of cotton produced at varying plant densities. Agronomy Journal, vol. 97, pp. 235-240.

ECHER, F.R. and ROSOLEM, C.A., 2015. Cotton yield and fiber quality affected by row spacing and shading at different growth stages. 
European Journal of Agronomy, vol. 65, no. 4, pp. 18-26. http:// dx.doi.org/10.1016/j.eja.2015.01.001.

GWATHMEY, C.O. and CLEMENT, J.D., 2010. Alteration of cotton source-sink relations with plant population density and mepiquat chloride. Field Crops Research, vol. 116, no. 1-2, pp. 101-107. http://dx.doi.org/10.1016/j.fcr.2009.11.019.

IQBAL, Z., SATTAR, M.N., KVARNHEDEN, A., MANSOOR, S. and BRIDDON, R.W., 2012. Effects of the mutation of selected genes of Cotton leaf curl Kokhran virus on infectivity, symptoms and the maintenance of Cotton leaf curl Multan betasatellite. Virus Research, vol. 169, no. 1, pp. 107-116. http://dx.doi.org/10.1016/j. virusres.2012.07.016. PMid:22871297.

JORDAN, A.G., 2001. Management to increase strength. Cotton Physiology Today, vol. 12, pp. 4.

KUMAR, K.A.K., PATIL, B.C. and CHETTI, M.B., 2004. Effect of plant growth regulators on biophysical, biochemical parameters and yield of hybrid cotton. Karnataka Journal of Agricultural Sciences, vol. 16, no. 4, pp. 591-594.

LV, F., LIU, J., MA, Y., CHEN, J., KEYOUMU.ABUDUREZIKEKEY, A., WANG, Y., CHEN, B., MENG, Y. and ZHOU, Z., 2013. Effect of shading on cotton yield and quality on different fruiting branches. Crop Science, vol. 53, no. 6, pp. 2670-2678. http:// dx.doi.org/10.2135/cropsci2013.03.0170.

MANJUNATHA, M.J., HALEPYATI, A.S., KOPPALKAR, B.G. and PUJARI, B.T., 2010. Influence of different plant densities on the growth, yield and economics of Bt cotton (Gossypium hirsutum L.) genotypes under dryland condition. Karnataka Journal of Agricultural Sciences, vol. 23, no. 4, pp. 580-583.

NAWAZ, H., HUSSAIN, N., REHMANI, M.I.A., YASMEEN, A. and ARIF, M., 2015. Comparative performance of cotton cultivars under conventional and ultra-narrow row (UNR) spacing. Pure and Applied Biology, vol. 5, no. 1, pp. 15-25.

OOSTERHUIS, D., 2001. Physiology and nutrition of high yielding cotton in the USA. Informações Agronômicas, vol. 95, pp. 18-24.

RAMEY, H.H., 1999. Classing of fiber. In: C. WAYNE SMITH and J. TOM COTHREN, eds. Cotton: origin, history, technology and production. New York: John Wiley \& Sons.
ROSOLEM, C.A., OOSTERHUIS, D.M. and SOUZA, F.S., 2013. Cotton response to mepiquat chloride and temperature. Scientia Agrícola, vol. 70, no. 2, pp. 82-87. http://dx.doi.org/10.1590/ S0103-90162013000200004.

SAWAN, Z.M., MAHMOUD, H.M. and EL-GUIBALI, A.H., 2006. Response of yield, yield Components, and fiber properties of Egyptian cotton (Gossypium barbadense L.) to nitrogen fertilization and foliar-applied potassium and mepiquat chloride. Journal of Cotton Science, vol. 10, no. 3, pp. 224-234.

STEEL, R.G.D., TORRIE, J.H. and DEEKEY, D.A., 1997. Principles and procedures of statistics: a biometrical approach. $3^{\text {rd }}$ ed. New York: McGraw Hill Book. Int. Co.. pp. 400-428.

VENUGOPALAN, M.V., KRANTHI, K.R., BLAISE, D., LAKDE, S. and SHANKARANARAYANAN, K., 2013. High density planting system in cotton-The Brazil Experience and Indian Initiatives. Cotton Research Journal, vol. 5, no. 2, pp. 172-185.

WILSON JUNIOR, D.G., YORK, A.C. and EDMISTEN, K.L., 2007. Narrow-row cotton response to mepiquat chloride. Journal of Cotton Science, vol. 11, no. 4, pp. 177-185.

WRIGHT, D.L., MAROIS, J.J., SPRENKEL, R.K. and RICH, J.R., 2011. Production of ultra-narrow row cotton. Gainesville (FL): University of Florida (UF). IFAS Extension. SSAGR-83.

YASMEEN, A., ARIF, M., HUSSAIN, N., MALIK, W. and QADIR, I., 2016. Morphological, growth and yield response of cotton to exogenous application of natural growth promoter and synthetic growth retardant. International Journal of Agriculture and Biology, vol. 18, no. 06, pp. 1109-1121. http://dx.doi.org/10.17957/IJAB/15.0213.

YASMEEN, A., ARIF, M., HUSSAIN, N., NAZ, S. and ANWAR, A., 2018. Economic analyses of sole and combined foliar application of moringa leaf extract (MLE) and $\mathrm{k}$ in growth and yield improvement of cotton. International Journal of Agriculture and Biology, vol. 20, pp. 857-863.

YASMEEN, A., BASRA, S.M.A., FAROOQ M., REHMAN, H.U., HUSSAIN, N. and ATHAR, H.U.R., 2013. Exogenous application of moringa leaf extract modulates the antioxidant enzyme system to improve wheat performance under saline conditions. Plant Growth Regulation, vol. 69, no. 3, pp. 225-233. http://dx.doi. org/10.1007/s10725-012-9764-5. 